31 Bosch FX, Castellsague X, De Sanjose S. HPV and cervical cancer: screening or vaccination? $\mathrm{Br} J$ Cancer 2008; 98: 15-21.

32 Sheridan A, White JL, Barlow T, Soldan K. Annual HPV Vaccine Uptake in England: 2008/09. February 2010. http://www.dh.gov.uk/prod_consum_dh/groups/dh_digitalasset s/@dh/@en/@ps/documents/digitalasset/dh__111676.pdf [Accessed 3 February 2010].

33 Steller MA. Human papillomavirus, it's genes... and cancer vaccines. Cancer Cell 2003; 3: 7-8.

34 Cancer Research UK. Cervical cancer vaccine http://www.cancerhelp.org.uk/help/default.asp?page $=16024$ [Accessed 3 February 2010].

35 Paavonen J, Naud P, Salmerón J, Wheeler CM, Chow SN Apter D, et al. Efficacy of human papillomavirus (HPV)-16/18 AS04-adjuvanted vaccine against cervical infection and precancer caused by oncogenic HPV types (PATRICIA): final analysis of a double-blind, randomised study in young women. Lancet 2009; 374: 301-314.
36 Munoz N, Kjaer SK, Sigurdsson K, Iversen O, HernandezAvilla, Wheeler CM, et al. Impact of human papillomavirus (HPV)-6/11/16/18 vaccine on all HPV-associated genital diseases in young women. J Natl Cancer Inst 2010; 5 February [Epub ahead of print].

37 Castellsagué X, Schneider A, Kaufmann AM, Bosch FX. HPV vaccination against cervical cancer in women above 25 years of age: key considerations and current perspectives. Gynecol Oncol 2009; 115(3 Suppl.): S15-S23.

38 Hellsten C, Sjostrom K, Lindqvist PG. A prospective Swedish cohort study on psychosocial factors influencing anxiety in women referred for colposcopy. Br J Obstet Gynaecol 2007; 114: 132-138.

39 Freeman-Wang T, Walker P, Linehan J, Coffey C, Glasser B, Sherr L. Anxiety levels in women attending colposcopy clinics for treatment for cervical intraepithelial neoplasia: a randomised trial of written and video information. $\mathrm{Br} \mathrm{J}$ Obstet Gynaecol 2001; 108: 482-484.

\title{
FACULTY OF SEXUAL \& REPRODUCTIVE HEALTHCARE MEMBERSHIP EXAMINATION
}

The Membership Examination (MFSRH) consists of:

$\checkmark$ Part 1 Multiple Choice Question paper (MCQ)

The London-based examination is held annually in April and October. Applications for the April examination must be received by 1 January. Applications for the October examination must be received by 1 July. The new syllabus for the Part 1 is on the Faculty website

\section{$\square$ Evidence Based Commentary (EBC)}

Candidates can view the released topic and candidate guidance notes for EBC on the Faculty website. There is an absolute deadline of $\mathbf{3 1}$ August $\mathbf{2 0 1 0}$ to submit the EBC on this topic

\section{ב Part 2 Examination (CRQ, EMQ, OSCE)}

This 2011 all-day examination will consist of:

\section{- $\quad$ Critical Reading Question examination paper (CRQ) \\ - Extended Matching Question examination paper (EMQ) \\ - $\quad$ Objective Structured Clinical Examination (OSCE)}

Applications for the MFSRH Part 2 held in June 2011 must be received by 3 January 2011.

The new Part 2 Syllabus, Membership Examination Regulations and sample EMQs will be posted on the Faculty website at the end of June 2010.

The qualification is subject to re-certification every 5 years

For the current MFSRH Examination Regulations, information on all components of the MFSRH examination and application forms, please visit the Faculty of Sexual and Reproductive Healthcare website: www.fsrh.org (Training \& Exams and Membership Exam) or e-mail Denise Pickford: denise@fsrh.org.

\section{JOIN THE PANEL OF MFSRH EXAMINERS}

The Faculty Examination Committee invites applications to join the panel of MFSRH Examiners for the Membership Examination. Applications are sought only from those able to fully commit to all examiner duties and who meet the following criteria:

- To be accredited Members of the Faculty and active clinically in the sphere of the Faculty or to be Clinicians, of equivalent status, with an interest in Sexual and Reproductive Healthcare but whose speciality is Genitourinary Medicine (GUM), Public Health Medicine, Gynaecology or Primary Care.

- To be able to show excellence in the quality of patient care, research skills or teaching skills relevant to the sphere of the Faculty.

- To hold or have held the Faculty Letter of Competence in Medical Education or equivalent.

Further information and the examiner CV application form are available on the Faculty website: www.fsrh.org (Training \& Exams, Membership Exam, MFSRH Examiners). The closing date for applications is 1 June 2010 and the form should be sent to the Examination Secretary, Examinations, FSRH, 27 Sussex Place, Regent's Park, London NW1 4RG, UK. Tel: +44 (0) 207724 5629. Fax: +44 (0) 2077235333. 